\title{
Library Management in the Implementation of School Literacy Movement in Primary Schools
}

\author{
Septiyati Purwandari ${ }^{1 *}$, Ella Minchah Awaliya ${ }^{1}$, Anisah $^{1}$ \\ ${ }^{1}$ Department of Primary Teacher Education, Universitas Muhammadiyah Magelang, Magelang, Indonesia \\ "Corresponding author.Email: septiyandari@ummgl.ac.id
}

\begin{abstract}
The role of library as the heart of school has not been fully understood by the school community. The lack of skill in information literacy among the librarians and teachers become the main consideration for this research. The aim of this research is to observe the library management in supporting the Gerakan Literasi Sekolah/GLS (School Literacy Movement). The benefit of the research results is to make the school management able to make a technical effort to improve the information literacy in terms of library management by creating a program for the improvement of collaboration of teachers and librarians for achieving an optimal output of GLS in stimulating the reading interest among students. This research was conducted in Magelang Regency with 5 primary schools as the research subjects, on balance, representing the characterics of: type of primary schools (private school and state school), being equipped with library, implementing the GLS program. The instruments used in this research included observation, interview and documentation and the method in data processing used the data reduction, data presentation and drawing conclusions. Meanwhile, the data validity used the data triangulation. The results of this research showed that first the synergy of library roles with the literacy movement was pragmatic meaning to move and distribute the books in each class through the Reading Corner activitity; second, the Guidelines for SNP library management had been fulfilled by the school as the administrative obligation; third, awareness of information literacy for teachers and principal in library management was categorized into the low level and fourth, the comprehension of the implementation of technical instructions of GLS by the school communities were still limited only in the phase 1.
\end{abstract}

Keywords: library management, GLS, primary school

\section{INTRODUCTION}

Library is the symbol of academic life in education institution. It is used as a facility to broaden the insight and knowledge among school communities. In the study [1], library is stated to play a critical role as a learning source predicted to bring an effect on the students' achievement. Key, in the book about the crisis of school libraries in Canada argued that a good library management can bring a learning impact for a lifetime for both students and teachers. Hence, the existence of school library is not simply about the storage of lesson books but it must be capable of being the references for the life values for the students. This issue has then become an essential part for the strategic planning of Ministry of Education and Culture in the period of 2015 2019; one of which was the education paradigm. To trigger Indonesia to have the regional competitiveness, the government attempted to build the characters of students through the culture of school ecosystem manifested in Gerakan Literasi Sekolah or GLS (the School Literacy Movement). In essence, GLS obliges each of student to read the local reading books and folklores that contain the local wisdom before the learning process begins [2].

This movement has been started since 2016. In the study of [3] GLS was stated failed to stimulate the reading interest among students. A number of obstacles in the GSL implementation might include (1) the low awareness among teachers, (2) lack of references that are comply with the needs, (3) lack of understanding among teachers about the implementation of school literacy movement and (4) limited financial support [4]. A previous research has been done regarding the GLS implementation. In [5] the results of the research strengthened the findings that the obstacles in the GLS implementation was related to the awareness of students and teachers to be continually consistent in implementing the GLS activities. This finding was also supported by a relevant research by Hidayah that made a conclusion that many school managements were hopeless with the GLS instruction as they did not totally understand about the indicators of GLS success. Here, the literacy has been simply interpreted only as reading and writing. In turn, it is affirmed in this research that the reading and writing habit will be successful only for the students that already have had this habit since their childhood.

Then, will the GLS Program be in the same condition as the role of library? The former researchers might be unaware of this statement. In fact, the library is supposed to be the initial and final point in the efforts to make a change in the literacy behaviors as a result of GLS. Most of previous research were more focused on the discussion of GLS implementation in terms of the phase of reading habit prior to start the class. They were not the in-depth study related to what and how the school should do for the refinement. GLS 
implementation held in school is a program that must be obeyed. So far, there is no any research on the understanding of the school management about the meaning of library as the core of the school. In fact, the school has declared itself as the literacy school. Interestingly, this current research was conducted in a primary school implementing GLS with the characteristics as the state and private schools equipped with the library. The criteria of the implementation included good, fair and moderate in accordance with the higher level of education institutions. This research through observation, documentation and in-depth interview attempted to find the answer for the obstacles and measures that can be done for school literacy revitalization through library.

\section{RESEARCH METHOD}

This is an explorative research using the inductive approach aimed to disclose the initial data from a concept for the development of its new concept. The sampling was conducted in 5 (five) primary schools in Magelang regency and city by means of purposive sampling technique. The criteria of sampling included the characteristics of primary school type (private school/state school), being equipped with a library and implementing GLS program. Meanwhile, the subjects in this research were the students, teachers, principal and librarians. Here, the supervisor of primary school acted as a supporting subject. Data collection was conducted using the observation, interview and documentation. The documentation was used to analyze the primary data, i.e. the administration of GLS implementation, library administration such as the attendance list, list of borrowing books and data of book collection. Meanwhile, observation was done to observe the process of GLS implementation, interaction of students and books, facilities and infrastructure of library and library management. The indepth interview was done with students, teachers, principal and library staff to observe the reading behavior, the GLS implementation process, GLS understanding and library management. The data subsequently were processed through a qualitative approach by means of data reduction, data classification, data presentation and conclusion. For this, the data validity was conducted by comparing and rechecking the trust level of the information obtained through the different times and tools (check \& re check) between the first researcher and researcher's assistant with a support of the observers with the theoretical concept.

\section{RESULTS AND DISCUSSION}

\subsection{GLS Implementation}

As found from the observation, the school has improved the concept of library management since the issue of School Literacy Movement program. All standards settled to be used as the reference in managing the library have sufficiently been represented through the GLS program. This program has made the students are familiar with book, and has involved the teachers in doing collaboration. From FGD, it was found that the effort of school to socialize the library could be done by the government program that is School Literacy Movement. In line with the technical instruction made by the government to be used as a reference for the school, then the schools have attempted to socialize the books to the children as summarized in the following table:

Table 1 Integration of School Literacy Movement

\begin{tabular}{|lll|}
\hline No. & \multicolumn{1}{c|}{$\begin{array}{c}\text { Name of } \\
\text { School (initial) }\end{array}$} & \multicolumn{1}{c|}{ Form of Integration } \\
\hline 1. & SDN A & $\begin{array}{l}\text { POJOK BACA (Reading Corner) } \\
\text { in each class corner }\end{array}$ \\
\hline 2. & SDN B & $\begin{array}{l}\text { Study at Library: cooperation of } \\
\text { teachers and librarians in using the } \\
\text { information available in library }\end{array}$ \\
\hline 3. & SDN D & $\begin{array}{l}\text { The Mandatory Visit schedule in } \\
\text { which the teachers ask the students } \\
\text { to borrow the book for making } \\
\text { resume and the reading output will } \\
\text { be shown in Wall-Magazine in the } \\
\text { class }\end{array}$ \\
\hline 4 & $\begin{array}{l}\text { In collaboration with public library } \\
\text { of Magelang City } \\
\text { in collaboration with Committee } \\
\text { and parents to make POJOK } \\
\text { BACA (reading corner) in each } \\
\text { class corner }\end{array}$ \\
\hline $\mathbf{5}$ & SD H & $\begin{array}{l}\text { The Mandatory Visit schedule is } \\
\text { once a week for each class based } \\
\text { upon the schedule of ICT. } \\
\text { Historical movie screening to } \\
\text { attract the students to visit to } \\
\text { library }\end{array}$ \\
\hline
\end{tabular}

The table above shows that with the GLS Program from government, the problem in reading interest can have an alternative solution. One of the GLS programs is to socialize the books for the students. For this, the provision of bookshelves and book collection in each class is a must. Such condition shows the efforts of any schools to integrate the program to the learning program. In the GLS implementation, the government has published the Grand Design of GLS literacy in the technical instructions to enable the school to technically implement any activities required.

\subsection{Has the reading corner given an impact on the reading interest among students?}

The response for the question given by the teachers could not be assessed; however, the situation of the students in reading could be nurtured. This was because the reading activity among students was the assignment from the teachers. Book reading system before the class has made the reading situation by the students could be seen every day before the class starts. Are the students enthusiastic to read in the hour outside the literacy program? $95 \%$ of school has given the response "not enthusiastic" From the in-depth interview, the teachers realized that the main factors might be related to the limited number of books and the way to stimulate the book exploration. Such condition is strengthened with the results of the study by Elizabeth stating that $77 \%$ of teachers found 
it difficult to integrate the information literacy into lessons. Additionally, the teachers have no idea about the significance to integrate the library for learning effectiveness. For the administrative fee, the teachers had no ideas for what would be done after reading the book to explore the students more. This information then implied an important message that the integration of library into the class in the form of reading corner was not able to give a significant impact on the reading interest among the students. This then showed an important statement for us that the teachers were not aware of the essence of library. A number of facts were found that the understanding of teachers about the roles of librarians as the resource providers was still low due to the narrow perspective of teachers about the information literacy. Eventually, the collaboration level between teachers and librarians of library staff was found low [6].

\subsection{Library Management}

Library as the core part of school has been much ignored. All libraries studied in the object of primary schools did not have a particular librarian in charge of managing the library. The library management system was by applying the picket system by teachers to maintain the library. Furthermore, there was no any SOP (Standard Operational Procedure) and the evaluation in doing this task. The obstacles faced by the school to manage the library were related to the variety of book references and the absence of the personnel that focus on managing the library. The awareness of managing the library was not the main priority and the book collection of libraries was still limited to the school books. These findings then led us that library as the heart of education is not managed well yet. Also, the library can change the student's attitude that is reading habit. Whenever this occurs, then it can bring an impact on the academic achievement of the students. It is because the library is the center for the student for discussion, sharing and stimulating the thinking analysis among students. To make the government measure in managing the library in the school assessed in terms of the quality, the National Regulations of Library of Indonesia Republic was issued in 2011 on the National Standards of Library or SNP 007: 2011. The government provides a minimum standard of library containing the directions in management. This then helps the schools to achieve the optimal library management. In the document, there are six components needed for the library to conform to standards. First, Book Collection. Based upon the observation and interview, all schools had the adequate book collection. This then showed that the government has given a help in the form of book collection that is in line with the standards determined. Uniquely, literature reading books for students are not included in the standard rules. In fact, the literature books contain the characters, local wisdom and insight highly needed as the base of ideas of the students. The availability of reading books containing the values and references was found minimum in number. All schools had no good understanding about the management of reading books [7]. They were aware of this significance, yet they had no ideas about how to do. This information implied a critical message about the rationale to result in an important policy about the need of school for holding a workshop for teachers and librarians about the exploration of literature books for children in which it will explore about the qualified book, the meaning of the story and impact of qualified reading for the positive behavior of children. The basic understanding is how to explore a book as a strategic step for the teachers to have a reading interest. It has been found out that all teachers and librarians stated that none of them have ever joined the workshop on the story book exploration for the students. Such condition reflects a critical message about how the students can enjoy reading the book if the teachers and adult people surrounding have not found the pleasure in reading the book. For this, it needs a literature teacher with an open minded, learning-oriented to revitalize the literacy in the class.

The second component is related to the infrastructures and facilities. The results showed only $20 \%$ of schools ( 1 state school and 1 private school) that had the criteria of library building. The fulfilment of the ideal criteria in accordance with the National Standards of Library was not found so far. The condition of library needed to be well concerned. The results showed that the library development was not the main school priority as it was more focused on the completeness of infrastructures and facilities related to learning. Why the infrastructures and facilities for library clearly had more inequality among schools? The response for this question was qualitatively analyzed and categorized into two points: finance and perception of interest. For the state school, the provision of infrastructures and facilities will be obtained from government; while, for the private schools, it would be dependent upon the school revenue related to the number of students. However, this information might be inharmonious if related to the perception of interest. For the state schools that have a good effort to develop the literacy culture, the local government will fully give a support in the form of financial aid and other facilities. The stimulant fund will be consistently allocated if the state schools are able to show an optimal output. Conversely, for the state schools that have the perception that library management is not something core, and they also have the low efforts for the library development, it is potential to find the quite alarming condition of infrastructures and facilities in library. Based upon the information, it can be stated that the assumption of the school to wait the financial aid from the government for the development of literacy culture is unfounded. This can be proven from the private schools that are able to compete with the state schools in terms of library management. The various problems in infrastructures and facilities of library can be coped with as long as the main vision of the school is to focus on the library as the learning center. The awareness of the library management as the main priority can make the school literacy culture come true. In line with the point, in [8] it is stated that the strategy of library promotion is important to be done; however, it must be accompanied with the improvement in physical and non-physical quality including provision for the special personnel of library.

The third component is about the service. Based on the observation and interview, there was only one school that had the service hours and librarian and the visit hours from $07.00-13.00$. This school was active to join the training on the library management and workshop for the improvement of librarian capacity. What is the meaning of library service? 
The response for this question was qualitatively analyzed and categorized into 3 concepts: circulation, contest and reading service. The school without any library users will see the library service as the service of book circulation required by all school communities, in this case in the form of enrichment books and the latest textbooks in addition to the service of the distribution of packet borrowings to the students in every year. Meanwhile, the perception of library as the service for the contest events included the contest of wall-magazines, poems and any contests related to the literacy activities.

Most of school community dominantly interprets the library as the place for the reading service. In line with this, only one school had a response for the consistent visit of students. All schools had the mandatory visit program, yet they were not ready to give innovation of the response for the visit. The library management in this case did not give any innovation for the visit of the students to create a good impression from the visit. $95 \%$ of the students' response showed that their visit was simply as the mandatory one. A study on the documentation in field about the graph of students' visits to library showed only one school showing a stable increase in each year. This is not the something bad, however. The school literacy movement is a practical solution for the low rate of the students' visit to the library. The Reading Corner Program is a program stimulating the students to get used to read the books. It is expected that by presenting the books in the classroom, it can create a library nuance in the class. The results showed that all schools have implemented the reading habit activities 10 minutes before the class starts. The students take the books from the reading corner made in their class. In this case, it reflects the significant role of teachers to create literacy in the class.

Furthermore, other two components are the Library Staff of School or Madrasah and Implementation. Based upon the observation and documentation, all schools have not fulfilled the standard of library staffs and implementation. For the state primary school, the library staffs are highly reliant on the decision of the local government for the proposal submitted by the school. As stated in the previous discussion, the condition of the library staff is highly determined by the vision and mission of the school itself. One of the private schools, for instance, managed this problem by self-reliantly positioning a staff that can also act as the school administrator. Certainly, the standards of library staff as determined by the government are to create the optimal and ideal implementation. Here, the school is quite creative in responding such condition. For the component of implementation, it is highly determined by the condition of human resources. It is because the implementation is highly related to the existing organizational structure. The obstacle in the school library management is related to the absence of the personnel or staff that, in particular, are in charge of managing the library. However, this can be managed by the teachers through certain mechanism and system by the school policy to create the creativity in optimizing the library as the learning sources. This is due to the effectiveness of library management brings an impact on the growth of reading interest and the improvement of student's achievement [1]. The results of the research showed that all schools had an organization structure in job description in implementing the library, yet it was limited only in administrative matter. There was no any effort in managing the problem in terms of effectiveness. Ineffectiveness in the implementation of the programs in the organization structure showed that the school had not prepared the innovation in the program to make the library more attractive considering that library should be a place for recreational-educative space for all students.

The management standards provided for the schools to make library as a base of strategic policy can lead the schools to be qualified. However, as stated previously, the existing respondents in this research did not show any development of education quality through library as a strategic policy. This certainly makes sense as the main problem is related to the literacy awareness in the teachers themselves. Teachers, principal, and educational staff had no interest in literacy of reading interest and this certainly has become the problem in managing the library. This information leads to the conclusion question if there is a literacy of information on the library management in the school community. Response to this question shows that there was no any literacy of the information about the library management to the school community. Even for the teachers, they assumed that the library service is not a part of their tasks. As a result, the new information about the development of children books have been found rare. This answer is relevant for the schools that have the library. In line with this, a number of research explained that teacher is someone with an important contribution to build the information literacy to the students [9]. This finding then leads to a statement that the information literacy towards library continually must be a part of training materials for the teachers (new teachers) for upgrading to realize the collaboration in library management.

\section{CONCLUSION AND SUGGESTIONS}

The implementation of School Literacy Movement has only been done to move the books into the class named Reading Corner to facilitate the reading habit for 15 minutes before the class starts. In fact, the Grand Design of GLS has clearly presented the guidelines to be implemented. There are 3 phases: habitual phase, development phase, and learning phase. Overall, since 2016, the schools have implemented this program only in the habitual phase by introducing the books to the students and teachers physically without understanding the real meaning of the school literacy movement program. The role of library as the center for school civilization in building the culture was not the concern for the stakeholders. The natures in the implementation of GLS are not simply about how the students will have a reading interest, but more principally about how the teachers are able to change to be the literate teachers that have skill in information and are willing to collaborate to improve the quality of library management. For this, there is a need for the grand design in the form of concrete measures to be the literate teachers, the collaboration for innovation in library management and the evaluation devices for the implementation of GLS program to make the program controllable and measurable. The Grand design should be in the form of manual book that can 
[5] B. H. Pradana, N. Fatimah, dan T. Rochana, "Pelaksanaan Gerakan Literasi Sekolah Sebagai Upaya Membentuk Habitus Literasi Siswa Di Sma Negeri 4 Magelang," J. Solidar., vol. 6, no. 2, hal. 167-179, 2017.

[6] E. R.A dan Llen, "The Impact of School Libraries on Student Achievement in North Carolina Charter Schools. A Master's Paper for the M.S. in L.S. degree. December, 2007. 25 pages. Advisor: Evelyn H. Daniel.," education, 2007.

[1] M. S. Kamulyan dan F. Primasari, "Implementasi Perpustakaan Sekolah sebagai Sumber Belajar dalam Meningkatkan Prestasi Belajar Siswa," Profesi Pendidik. Dasar, vol. 1, no. 1, hal. 17-30, 2014.

[2] M. Hidayat, I. Basuki, dan S. Akbar, "Gerakan literasi Sekolah Dasar," J. Pendidik. Teor. Penelitian, dan Pengemb., vol. 3, no. 6, hal. 810-817, 2018.

[3] N. Yenice dan H. Aktamiş, "Determination of multiple intelligence domains and learning styles of the teacher candidates," Procedia - Soc. Behav. Sci., vol. 2, no. 2, hal. 3274-3281, 2010.

[4] H. Husein, "Implementasi GLS di SDN Gugus Sungai Miai Banjarmasin," Jpsd, vol. 4, no. 1, hal. 1, 2018.
[7] Nindya Faradina, "Pengaruh program gerakan literasi sekolah terhadap minat baca siswa di SD Islam Terpadu Muhammadiyah An-Najah Jatinom Klaten," Hanata Widya, vol. 6, no. 8, hal. 60-69, 2017.

[8] Hari Santoso, "Promosi Sebagai Media Pemberdayaan Perpustakaan Sekolah," J. Perpust. Sekol., vol. 1, no. 6, hal. 1-8, 2007.

[9] E. Mulyasa, Pembinaan dan Pengembangan Pendidikan di Sekolah Dasar. Bandung: CV. Geger Sunten, 2001. 